\title{
Domestic food waste - the carbon and financial costs of the options
}

Tim D. Evans MS, PhD, CChem, CEnv, FCIWEM, MRSC

Tim Evans Environment, Stonecroft, Ashtead, UK

Food waste is the most difficult waste fraction of household waste to manage because it is wet and putrescible. It becomes odorous and it attracts flies and scavengers. When it sticks to other wastes, it reduces the yield of dry recyclables. Home composting has the benefit of proximity but many are unwilling or unable to practise it. Source segregation and storage for kerbside collection and treatment works for many households but not for all, participation is especially low among households in flatted properties. The in-sink food waste disposer (FWD) is used extensively in Australia, New Zealand and the USA but it has been relatively underutilised in Europe. Using data from the published literature, the global warming potentials for landfill, incineration and centralised composting were calculated to be respectively $+743,+13$ and $-14 \mathrm{kgCO}_{2} \mathrm{e} / \mathrm{t}$ food waste; anaerobic digestion was approximately $-170 \mathrm{kgCO} 2 \mathrm{e} / \mathrm{t}$ food waste irrespective of whether the food waste is delivered by truck or by FWD and the public sewer. Surahammar in Sweden has provided a unique opportunity to assess the impacts of FWD at community scale and compare them with results from laboratory studies and field trials. Over 14 years, FWD installation went from zero to $50 \%$ of households voluntarily; 4-weekly influent monitoring data from the wastewater treatment works of the town show that biogas increased by $46 \%$ but flow (water use) and chemical and biological load did not change significantly.

\section{Introduction}

Quantifying the amount of domestic food waste produced can only really be accomplished by sampling and bin analysis. Quested and Johnson (2009) estimated that 5.8 million $\mathrm{t} / \mathrm{year}$ of food waste are collected by local authorities in the UK. (Note that in the current paper ' $t$ ' is used to denote tonne $(1000 \mathrm{~kg})$ fresh waste unless shown as dry solids (DS).) It is mainly in the residual waste stream (general bin). They reported that in addition 0.69 million tonnes are home composted or fed to animals. The Office of National Statistics reported there were 24.9 million households (hhd) in the UK in 2006. This equates to $233 \mathrm{~kg}$ food waste per hhd.year collected by local authorities mainly as residual waste. Food waste collection for feeding to pigs was practised for centuries but was banned in the UK and then in the whole European Union (EU) following an outbreak in 2001 of foot and mouth disease after the original infection had been attributed to infected meat that had not been cooked in the legally required manner. It might have been better to tighten enforcement of the cooking requirements, which would be easy with modern sensors and telemetry, but we are where we are.

Europe has given emphasis to separate (kerbside) collection of biowaste for many years but even so a large proportion of biowaste is still in mixed waste, which makes resource recovery more difficult. The European Commission's Green Paper (CEC, 2008) on biowaste says that only $30 \%$ of biowaste is separately collected and treated biologically.

Data from the 2001 UK census and household waste statistics for England (the data for Scotland and Wales are not comparable) (Defra, 2010) show that the correlation coefficient between the percentage of flatted properties and NI192 (the percentage of household waste sent for reuse, recycling or composting) for all the London boroughs and the City of London is -0.529 (Figure 1); that is the data confirm anecdotal evidence of waste managers that a smaller percentage of household waste is sent for reuse, recycling or composting by households in flatted properties than households that are not in flatted properties. Flatted properties comprise $49 \%$ of London's housing and $71 \%$ in inner London. Even for all 325 waste collection authorities in England, the correlation is -0.368 (where 0 is unrelated and +1 or -1 is a perfect linear relationship with all points on the line). To be successful, any waste strategy must address this conundrum and present a range of options from which people can choose ones they are willing to use.

The EU Landfill Directive (CEC, 1999) requires member states (MS) to reduce the amount of biodegradable waste disposed to landfill in order to reduce methane emissions $\left(\mathrm{CH}_{4}\right)$. Methane has 25 times the climate change effect of carbon dioxide $\left(\mathrm{CO}_{2}\right)$ 


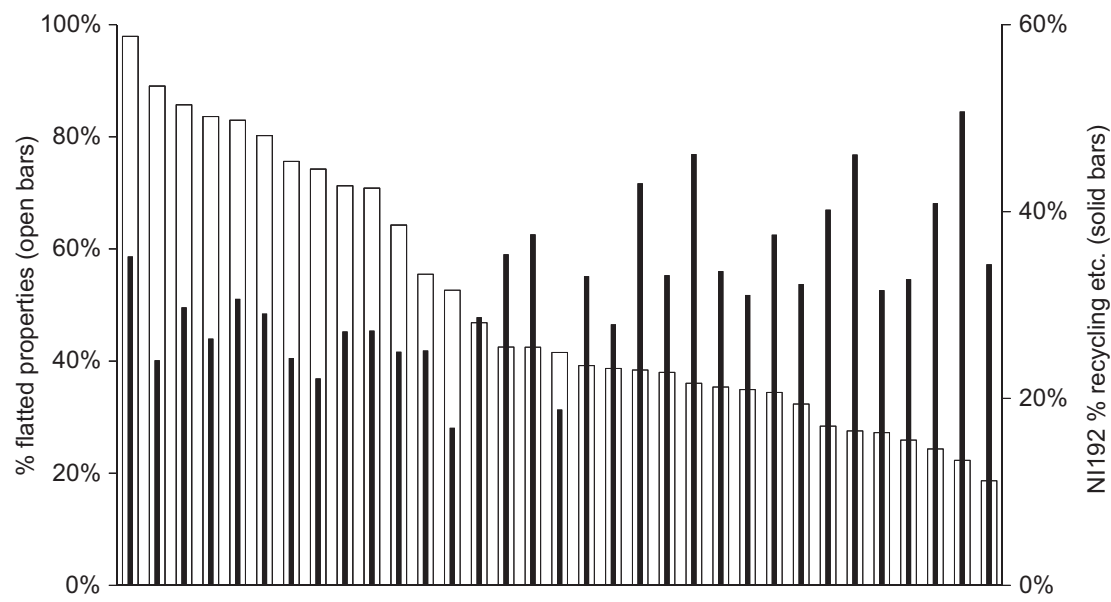

Figure 1. Negative correlation of percentage recycling with percentage flatted properties in London boroughs

over 100 years (IPCC, 2007). The EU also aspires to change from a disposal society to a recycling society.

'Kerbside' collection of source segregated wastes requires the solid waste from domestic and commercial premises to be stored in separate containers, collected separately and taken to treatment facilities. Dry recyclables (paper, glass, plastic and metal) can be segregated mechanically after collection but their value is reduced if they are contaminated with wet food waste (Yang et al., 2010). The biodegradable fraction of solid waste is generally composted or anaerobically digested (AD). Methane from $\mathrm{AD}$ is used to produce renewable energy and the digestate can be used as soil improver. Separate collection often necessitates extra truck traffic, especially during summer when it is not acceptable to store biodegradable waste for long periods prior to collection because of odour.

The food waste disposer (FWD) was invented in 1927 by architect John W. Hammes of Racine, Wisconsin, USA to be a convenience for his wife. After 11 years of development his company started manufacturing and selling FWDs in 1938. Some cities in USA mandated FWD for all new build residential properties. FWDs fit the standard drain outlet hole of kitchen sinks and there are adaptors for other sizes. FWDs comprise a 'grind chamber' which has perforated walls; the floor is a disc with lugs driven by an electric motor that spins the food scraps against the wall by centrifugal force. There are no knives in a FWD so it cannot cut plastic or fingers. FWDs operate with a stream of cold water (which could be the vegetable washing water); this conveys the ground food waste through the drains. Particles cannot escape the grind chamber until they are small enough to pass the outlet screen. The grind effectiveness does not deteriorate with time. When FWDs wear out it is because the bearings have failed: life is typically 12 years. FWDs are $95 \%$ recyclable at end of life (InSinkErator, private communication, 2010).

Field trials have found user satisfaction with FWD is high, for example, Nilsson et al. (1990) found 96\% satisfaction; Karlberg and Norin (1999) also reported 96\% satisfaction in the trial before launching FWD as an option; NILIM (2005) found 80\% of users would use FWD after their trial.

Today approximately $50 \%$ of households in the USA have a FWD; in some cities more than 90\% have them. Atwater (1947) reported that initially sewerage engineers in the USA were apprehensive that the output of FWDs might affect their sewers and/or wastewater treatment adversely, but after reviewing the experiences of about 300 municipalities he concluded that their fears were unfounded. New Zealand and Australia also have high rates of installation at more that $30 \%$ and more than $20 \%$ respectively. Installation in EU member states (MS) is $6 \%$ or less. However the density of installation in commercial kitchens is very much greater. Generally domestic food waste in the EU is dealt with as part of the solid waste system; however, in some MS interest in FWD is growing for reasons discussed below. For example, Stockholm Water has evaluated the evidence; it now encourages FWD installation and use because it wants more biogas (Gustafsson, 2008).

\section{Discussion}

Because FWDs are 'novel' in the European waste management context, the current paper discusses their impacts in relation to the other options. 


\subsection{Effects on sewers}

Several field studies have inspected sewers with and without FWD (e.g. Battistoni et al., 2007; Karlberg and Norin, 1999; New York City DEP, 1999; Nilsson et al., 1990) none reported any change in sediment accumulation or any other impedance to the flow. Nilsson et al. (1990) simulated 15 years of FWD use in a laboratory rig using a mixture of foods that included $8 \cdot 5 \% \mathrm{w} / \mathrm{w}$ lard and $1 \cdot 7 \% \mathrm{w} / \mathrm{w}$ margarine. They found no blocking of the pipes. Kegebein et al. (2001) measured the particle size distribution of FWD output using two mixtures of foods and also waste from the university's cafeteria. They found $40-50 \%$ of the output was $<0.5 \mathrm{~mm}$, $98 \%$ was $<2 \mathrm{~mm}$ and $100 \%$ was $<5 \mathrm{~mm}$ by sieve analysis; between 15 and $36 \%$ of the output was in their 'dissolved' fraction. They observed sediment-free transport at $0.1 \mathrm{~m} / \mathrm{s}$, which is well within design standards for sewers $(0 \cdot 48-0.9 \mathrm{~m} /$ s, Ashley et al., 2004).

Sewerage operators are rightly concerned about fat, oil and grease (FOG) which can block or severely impede sewers, but FOG is an entirely separate issue from FWD and requires proper attention (Ducoste, et al., 2008). NILIM (2005) in Japan found no deposits in sewers where FWD had been installed and no difference in n-Hex (fat, oil and grease). Fat, oil or grease should never be poured down drains. Lowmelting-point substances solidify on the cold walls but a different and more intractable substance forms by chemical reaction. Research suggests that this results from hydrolysis of FOG to form free fatty acids that saponify with calcium to form insoluble soaps. FOG samples analysed by Ducoste et al. (2008) were dominated by saturated fatty acids; they found no evidence of ground food waste fragments (Kevin Keener, Purdue University, private communication, 2010). They are found downstream of food service establishments particularly. Quite possibly, some passive grease traps are hydrolysis reactors releasing free fatty acids into the wastewater. Research into the subjects of FOG chemistry and of FOG separators is on-going and further results will assist development of better solutions. FOG has a large biogas yield so there is an opportunity for well-designed active-separators, installed appropriately, so that FOG can be collected and tankered away to anaerobic digestion and renewable energy generation (Larson, 2010).

\subsection{Water use}

FWDs use water to transport the ground food waste out of the grind chamber and through the drainage system. Field studies that have measured water use by households with and without FWD have shown water use is related to food preparation events, not to the number of people in a household.

Nilsson et al. (1990) metered 100 apartments and measured the duration of use per start and water use; duration was $38 \mathrm{~s}$, daily water use decreased from 183 1/person during the 6 months without FWD to 170 1/person during the 11 months with FWD. Jones (1990) monitored 45 homes for 2 months with FWD and 2 months without FWD. He concluded that the influence on water use was not significant within the overall 'noise' in measured water use. Ketzenberger (1995) reported a detailed stratified survey that found that FWDs are used for about $15 \mathrm{~s}$ per start irrespective of the number of people in the household; subjectively this seems sensible and would account for the range of reported water-use when expressed as litres per capita. Karlberg and Norin (1999) reported 3 years' monitoring when 32 out of 39 apartments were fitted with FWD; water consumption reduced by $25 \%$ during the survey period, which the authors did not wish to attribute to FWD even though they had no other explanation for the result.

The largest field study into FWD was in New York City. It involved 514 apartments with FWDs compared with 535 apartments without FWDs. They were in four different localities to reflect some of the city's diversity. The survey comprised 2014 people in total; it concluded 'There is no statistically significant evidence that any change in water consumption has occurred as a result of the installation of FWDs at the three test sites. Each site faced serious challenges to observing a change in water consumption'. It went on to assume for the purpose of predicting impact on water resources that there would be an increase of 1 US gallon per person per day but this seems to have been arbitrary and unconnected with the actual measurements made in the field study (New York City DEP, 1999).

Evans et al. (2010) found the flow into a wastewater treatment works (WwTW) did not change significantly between the time when there were no FWDs and when $50 \%$ of the 3700 households used FWDs.

On the basis of field studies, 5 1/hhd.day (less than one flush of a modern toilet) would be a conservative (upper) estimate of additional water use (approximately $1.5 \%$ ); this is of no consequence to sewer hydraulic capacity and negligible in terms of sewage pumping or water resources. The factor that stresses the hydraulic capacity of sewers is surface water; as far as possible, it should be controlled at source.

\subsection{Energy and global warming potential}

Domestic FWDs have a 350 to $750 \mathrm{~W}$ electric motor. Based on the field studies of usage discussed above under water use, the expected annual electricity consumption is $1.5 \mathrm{kWh}_{\mathrm{e}} / \mathrm{hhd}$.year, where $\mathrm{kWh}_{\mathrm{e}}$ denotes kilowatt hour of electricity.

Kegebein et al. (2001) estimated that where the WwTW receiving the kitchen food waste treated its sludge by $\mathrm{AD}$, the 
biogas from food waste would amount to approximately $300 \mathrm{MJ}$ (mega Joule)/resident.year, which corresponds to a heating value of 8 litres of diesel fuel or $183 \mathrm{kWh}$ (kilowatt hour) /hhd.year ( $2 \cdot 2$ people per household). At $40 \%$ electricity generation efficiency, this is $73 \mathrm{kWh} / \mathrm{hhd}$.year electricity generation, which at the EU average for electricity generation is a global warming potential of $-33 \mathrm{kgCO}_{2} \mathrm{e} / \mathrm{hhd}$.year $\left(\mathrm{kgCO}_{2} \mathrm{e}\right.$ denotes kilograms carbon dioxide equivalent - 100year global warming potential); that is, compared with the $+1 \mathrm{~kg} \mathrm{CO}_{2} \mathrm{e} / \mathrm{hhd}$.year used to run the FWD. In 2005, 64\% w/w of sewage sludge in England and Wales was treated by AD; by 2015 this will have increased to 85\% (Keith Panter, Ebcor Ltd., private communication, 2010).

Lundie and Peters (2005) concluded 'FWD performed well in terms of energy usage, climate change and acidification potentials, although it makes a large contribution to eutrophication and toxicity potentials. ... centralised composting has a relatively poor environmental performance due to the energyintense waste collection activities it requires. Implementing a separate collection and transportation system for organic waste results in relatively high environmental impacts due to the frequency of collections and the small quantities of green waste collected per household ... home composting is clearly the best option in terms of the categories examined in this LCA, there is an important caveat to this result. If operated without due care, home composting loses its allure due to the high greenhouse gas emissions consequent to anaerobic methanogenesis. Although home composting has the capacity to be the best food waste management option, it can also perform worst in relation to a subject in which Australia is already at the bottom of its class.' The question of methane from home composting has almost certainly been exaggerated. Smith and Jasim (2009) monitored home composting by 64 homeowners over 2 years and detected only traces of methane occasionally. They reasoned that, if formed in anaerobic microzones, methane would be oxidised by methanotrophic bacteria, which are ubiquitous.

Evans (2007) showed that the global warming potential (GWP) of delivering source segregated food waste to AD by way of FWDs and the sewers was equivalent to kerbside collection and transport to $\mathrm{AD}$ by road $\left(\approx-170 \mathrm{kgCO}_{2} \mathrm{e} / \mathrm{t}\right.$ food waste). Both routes to $\mathrm{AD}$ were better than composting, incinerating or landfilling food waste $\left(-14,+13\right.$ and $+740 \mathrm{kgCO}_{2} \mathrm{e} / \mathrm{t}$ food waste respectively). The incineration and landfilling scenarios both included energy recovery. The composting scenario was based on measurements performed on 16 in-vessel plants in the Netherlands reported by Smith et al. (2001); the plants' operating conditions pre-dated the Animal by-Products Regulation (CEC, 2002); operating under ABPR would have increased energy and carbon use somewhat so, if anything,
Evans (2007) understated the GWP of centralise composting $\left(-14 \mathrm{kgCO}_{2} \mathrm{e} / \mathrm{t}\right.$ food waste).

Based on the author's observations at waste treatment sites and discussions with operators, the inconvenient truths about separate collection of food waste are that people like to use bags or liners to keep their kitchen caddies clean and that cutlery and other items get into the waste by mistake. Riedel (2008) reported contamination (glass, metal, plastic) in household biowaste increased from $4 \%$ to $20 \%$ with time in Germany as householders became less diligent about sorting. Levis et al. (2010) reported at least $10-12 \%$ of compost feedstock in the US and Canada is glass, metal and plastic. Harrison (2010) reported that a food waste $\mathrm{AD}$ facility in Scotland is removing $20 \% \mathrm{w} / \mathrm{w}$ of the incoming material before digestion. Biodegradable bags degrade during composting but they are incompatible with wet AD. Fragments of plastic float and accumulate at the top of digesters; this raft of plastic would have to be removed periodically, which is expensive and hazardous because of the methane in the digester. Composting is reasonably tolerant of plastic, cutlery and other physical contaminants (although they might deteriorate compost quality), but they are incompatible with $\mathrm{AD}$ and resilient processes to remove them are essential; this is still an area for operational development. FWDs do not grind plastic, which therefore remains in the grind chamber and can be lifted out.

\subsection{Odour, rats and disease}

Unintended consequences of obliging people to store food waste might be nuisance (odour and vermin) and exposing them to health risks. The British Pest Control Association considered that since $98 \%$ of the ground food waste from FWDs is $<2 \mathrm{~mm}$, it would not be detectable by rats (Adrian Meyer, private communication, 2005) but spilled and poorly contained food on the surface would attract rats, gulls and other scavengers. Wouters et al. (2000) reported that keeping separated food waste in kitchens increases bioaerosols and allergens compared with mixed waste that contains food waste; they concluded this is a respiratory risk to susceptible individuals.

\subsection{Cost saving to waste collection and disposal agencies}

Evans (2007) analysed the audited 2005/06 performance data for Herefordshire and Worcestershire (two counties in England that cooperate on waste management). The average household waste collected (weighted by population in each collection agency) was $894.8 \mathrm{~kg} / \mathrm{hhd}$.year. The range for the collection agencies was $1145 \mathrm{~kg}$ to $743 \mathrm{~kg}$, reflecting that some offered kerbside collection of garden waste whereas others did not. The weighted average kerbside collection and disposal (including landfill tax) costs were respectively $£ 43.89$ and $£ 61.97 /$ hhd.year. If the proportion of food waste was $17 \cdot 6 \%$ (Hogg et al., 2007), the 
combined collection and disposal cost for food waste was $£ 18.63$ /hhd.year. The escalation of landfill tax would have taken this to more than $£ 30 /$ hhd.year in 2010 .

\subsection{Cost transfer to wastewater treatment}

Surahammar in Sweden provided Evans et al. (2010) with an opportunity to assess the cost transfer from solid waste to wastewater, because in the space of 12 years FWD installation changed from $0 \%$ to $50 \%$ of households and throughout this period the WwTW that serves the municipality collected and analysed 4-weekly, 24-hour composite samples of the influent. The sewerage is largely separate surface and sanitary sewers with interconnection to relieve excess flow. During the 14 years of monitoring data, there was no major change in the domestic population or in trade effluent (non-domestic) discharge.

The FWD installation resulted from the municipality introducing tiered charges for food waste management. People who home-composted food waste paid nothing, those who leased a FWD from the municipality (8-year lease) paid $£ 27$ per year and those who chose kerbside collection paid $£ 209$ per year. The charge for the residual waste bin was also related to usage. There was a bring system for cardboard, glass, metal and plastic (i.e. drop-off locations to which residents take these materials). The policy was effective in that the tonnage of waste to landfill from the municipality decreased from $3600 \mathrm{t} / \mathrm{year}$ in 1996 to 1400 t/year in 2007.

FWD installation started in May 1997. Surprisingly the mean flow and mean loadings of $\mathrm{BOD}_{7}$ (biochemical (or biological) oxygen demand (as $\mathrm{mgO}_{2} / \mathrm{l}$ ) for aerobic biological degradation of organic matter in water sample at certain temperature and time; '7' refers to 7 days, which is the standard time in Sweden), COD (chemical oxygen demand - measures organic matter degradable by a chemical oxidising agent, it is quicker than BOD. COD is typically 2 to $2 \cdot 5$ times BOD), nitrogen and ammoniacal-N were all less in December 2006 to April 2009 than they had been in January 1995 to April 1997, although the differences were not statistically significant (Table 1). Unfortunately, suspended solids were not one of the parameters in the analytical suite for the influent samples. The mean phosphate loading decreased 26\% $(P=0 \cdot 002)$, which was probably because of a contemporaneous change to phosphate-free and low-phosphate detergent products. Sweden introduced a voluntary limit of $7 \cdot 5 \% P$ in laundry detergents in 1970, which was so effective that the government was able to ban phosphate in laundry detergents from 1 September 2008 (as part of concerted action by Baltic countries) and to propose a ban of phosphate in domestic dishwasher detergents from 1 July 2011. Mean biogas production increased by $46 \%(P=0 \cdot 01)$. The extra biogas at $40 \%$ electricity generating efficiency would equate to $76 \mathrm{kWh}_{\mathrm{e}} /$ hhd.year electricity generation, which agrees very well with the $73 \mathrm{kWh}_{\mathrm{e}} / \mathrm{hhd}$.year predicted by Kegebein et al. (2001) from experimental work.

The median influent flow for January 1995 to April 1997 (before FWD) was $4020 \mathrm{~m}^{3} / \mathrm{d}$, whereas the median for midDecember 2006 to April 2009 (when 50\% of households had FWDs) was $3575 \mathrm{~m}^{3} / \mathrm{d}$. The scatter of results showed that despite maintenance work, a substantial amount of surface water and infiltration entered the sewers. Inevitably, some old domestic appliances will have been replaced by more water efficient ones during this 14 year monitoring period and this would result in some reduction in water use; overall there is no evidence that FWD affected the hydraulic loading on sewers.

The increase in biogas is evidence that the FWDs provide additional substrate for biogas production, presumably in the form of particulate material that settles in the primary tanks. The absence of change in BOD, COD or nitrogen is consistent with the observation of Karlberg and Norin (1999) that electricity use by the activated sludge plant had not changed as a result of FWD installation.

Sewers are linear bioreactors with some activity in the suspended biomass, which is flushed through continuously, and more in the biofilms attached to the sewer walls. DNA profiling has revealed that biofilm ecology differs from one location to another reflecting the sewage flowing past (Catherine Biggs, Sheffield University, private communication, 2009). Anammox bacteria, which convert nitrite and ammonia to nitrogen gas, are found in sewer slimes, estuary mud and anoxic or anaerobic ecological niches. The trends in the influent monitoring data (BOD, COD, $\mathrm{N}$ and $\mathrm{NH}_{4}{ }^{+}$) are consistent with a hypothesis that the biofilm ecology has acclimated to the change in sewage composition. The difference between the 120 week pre-installation data and the 533 week post-installation data are consistent with the hypothesis that sewer ecology acclimated to the additional dissolved and fine particulate load. It also indicates the duration of studies that is needed when interpreting field studies, because a short duration study would not have seen this important effect because there would not have been enough time for acclimation.

Thermal electricity generation uses about 80 litres water/kWh ; the UK's average electricity generation emission factor is $0.541 \mathrm{kgCO}_{2} \mathrm{e} / \mathrm{kWh}_{\mathrm{e}}$ (National Energy Foundation); it is greater than the EU average. The offset from the electricity from biogas is thus 60001 water and $41 \mathrm{kgCO}_{2} \mathrm{e} / \mathrm{kWh}_{\mathrm{e}}$, which is a net annual benefit (after deducting additional water and electricity to run the FWD) of about 41001 water and $40 \mathrm{kgCO}_{2} \mathrm{e} / \mathrm{hhd}$. year per household. 


\begin{tabular}{|c|c|c|c|c|c|c|c|c|}
\hline & Flow $\mathrm{m}^{3} / \mathrm{d}$ & $\mathrm{kgBOD}_{7} / \mathrm{d}$ & $\mathrm{kgCOD} / \mathrm{d}$ & $\mathrm{kgN} / \mathrm{d}$ & $\mathrm{kgNH}_{4} / \mathrm{d}$ & $\mathrm{kgP} / \mathrm{d}$ & $\mathrm{BOD}_{7}: \mathrm{N} \quad \mathrm{r}$ & $\mathrm{m}^{3}$ biogas $/ d$ \\
\hline $\begin{array}{l}\text { Mean pre FWD } 120 \text { weeks } \\
11 / 01 / 95-30 / 04 / 97\end{array}$ & 4706 & 408 & 1084 & $113 \cdot 6$ & $74 \cdot 0$ & $18 \cdot 0$ & $3 \cdot 50$ & 331 \\
\hline Variance & 3034123 & 46620 & 394192 & 979 & 405 & $49 \cdot 9$ & $1 \cdot 695$ & 1036 \\
\hline $\begin{array}{l}\text { Mean post FWD } 533 \text { weeks } \\
\text { 12/01/99-01/04/09 }\end{array}$ & 4538 & 381 & 1062 & 108 & 67 & $15 \cdot 4$ & $3 \cdot 55$ & 447 \\
\hline Variance & 7171537 & 38370 & 262063 & 1084 & 490 & $26 \cdot 6$ & $1 \cdot 902$ & 3005 \\
\hline Difference (post ${ }_{533}$-pre) & $-3 \cdot 7 \%$ & $-7 \cdot 1 \%$ & $-2 \cdot 0 \%$ & $-5 \cdot 3 \%$ & $-9 \cdot 5 \%$ & $-14 \%$ & $+1 \cdot 63 \%$ & $+35 \%$ \\
\hline$P$ (1-tail, $t$-test) & $0 \cdot 34$ & $0 \cdot 27$ & $0 \cdot 43$ & $0 \cdot 19$ & 0.06 & 0.04 & $0 \cdot 42$ & 0.002 \\
\hline $\begin{array}{l}\text { Mean early post FWD } 120 \\
\text { weeks 12/01/99-02/05/01 }\end{array}$ & 5194 & 520 & 1420 & 113.8 & $62 \cdot 4$ & $17 \cdot 5$ & $4 \cdot 60$ & 410 \\
\hline Variance & 13156275 & 69225 & 425475 & 1507 & 391 & $22 \cdot 4$ & $2 \cdot 341$ & $6 \cdot 937$ \\
\hline Difference (early post ${ }_{120}-$ pre) & $+10 \cdot 3 \%$ & $+27 \cdot 4 \%$ & $+31 \cdot 0 \%$ & $+0 \cdot 16 \%$ & $-15 \cdot 7 \%$ & $-2 \cdot 6 \%$ & $+31 \cdot 5 \%$ & $+23.9 \%$ \\
\hline$P(1$-tail, $t$-test $)$ & $0 \cdot 25$ & $0 \cdot 04$ & $0 \cdot 03$ & $0 \cdot 49$ & $0 \cdot 02$ & $0 \cdot 39$ & $0 \cdot 002$ & $0 \cdot 03$ \\
\hline $\begin{array}{l}\text { Mean late post FWD } 120 \\
\text { weeks 13/12/06-01/04/09 }\end{array}$ & 4678 & 331 & 892 & 107 & 71 & $13 \cdot 3$ & $3 \cdot 11$ & 484 \\
\hline Variance & 5675190 & 17138 & 167426 & 548 & 282 & $12 \cdot 7$ & $1 \cdot 191$ & 3147 \\
\hline Difference (late post $_{120}-$ pre) & $-0 \cdot 59 \%$ & $-19 \cdot 0 \%$ & $-17 \cdot 7 \%$ & $-6 \cdot 1 \%$ & $-3 \cdot 9 \%$ & $-26 \cdot 1 \%$ & $-11 \cdot 1 \%$ & $\%+46 \%$ \\
\hline$P$ (1-tail, $t$-test) & $0 \cdot 50$ & 0.06 & 0.09 & $0 \cdot 18$ & $0 \cdot 28$ & $0 \cdot 002$ & $0 \cdot 11$ & $0 \cdot 01$ \\
\hline
\end{tabular}

Table 1. Student's t-test comparing influent and biogas pre and post FWD installation (from Evans et al., 2010)

\subsection{Sludge production}

FWDs do add to biosolids production but the increase is small. Food waste is typically $70 \%$ moisture ( $30 \%$ dry solids) and $90 \%$ volatile solids (weight loss on ignition of the dry matter). It is very biodegradable; the volatile solids reduction during AD is about $90 \%$. Thus, $1 \mathrm{t}$ food waste (fresh weight) contributes about $50 \mathrm{~kg}$ dry solids to digestate production, which is recycled as part of the biosolids recycling programme with all of its proven safeguards (e.g., CEN, 2007; National Research Council, 2002; Smith, 1996, 2000). All of the nutrients in the food waste going into $\mathrm{AD}$ are retained in the digestate.

\section{Conclusions}

Practical experience and research into in-sink FWDs demonstrate that while apprehensiveness might be understandable, it is unfounded and FWDs constitute one of the viable tools for managing kitchen food waste. FWDs segregate food waste at source and have a high user satisfaction rate. Source segregation and storage of food waste for home composting or for kerbside collection is acceptable to many citizens but experience shows that a substantial proportion of the population is unwilling to participate in this means of recycling. FWD linked to the public sewer and delivering to WwTW is a valid means of diverting kitchen food waste from the general waste stream (and landfill). Treatment by AD creates non-fossil, baseload electricity. Use of biosolids from wastewater treatment on land is a well-demonstrated, safe means of completing nutrient cycles and conserving soil organic matter; integrating treated food waste is sensible.

\section{Acknowledgements}

The author is grateful to Ben Ramster, Editorial Coordinator of Municipal Engineer for encouraging him to write this paper and to Worcestershire County Council, The County Surveyors' Society, Insinkerator, Monsal, Scottish Water, Severn Trent and Yorkshire Water for funding time involved in this research and numerous colleagues for discussions, permission to visit sites and technical contributions.

\section{REFERENCES}

Ashley RM, Bertrand-Krajewski J-L, Hvitved-Jacobsen T and Verbanck M (2004) Solids in Sewers: Characteristics, Effects and Control of Sewer Solids and Associated Pollutants. IWA Publishing, London.

Atwater RM (1947) The kitchen garbage grinder. Editorial. American Journal of Public Health 37(5): 573-574.

Battistoni P, Fatone F, Passacantandoa D and Bolzonella D (2007) Application of food waste disposers and alternate cycles process in small-decentralized towns: a case study. Water Research 41(4): 893-903.

CEC (1999) Directive on the landfill of waste. (1999/31/EC) 
Council Directive. Journal of the European Communities 16.7.1999 No L 182/1.

CEC (2002) Regulation (EC) No 1774/2002 of the European Parliament and of the Council of 3 October 2002 laying down health rules concerning animal by-products not intended for human consumption. Official Journal of the European Communities L 273/1 10.10.2002.

CEC (2008) Green Paper On the management of bio-waste in the European Union. COM(2008) 811 final, Brussels, 3.12.2008 \{SEC(2008) 2936\}.

CEN (2007) CEN/TR 15584: Characterisation of sludges guide to risk assessment especially in relation to use and disposal of sludges. BSI, London.

Defra (2010) Local Authority municipal Waste Statistics Table 3: Local Authority Level Data Including Key Performance Indicators 2009/10. See www.defra.gov.uk/statistics/files/ mwb200910a.xls (accessed 29/01/2012).

Ducoste JJ, Keener KM, Groninger JW and Holt LM (2008) Fats, Roots, Oils, and Grease (FROG) in Centralized and Decentralized Systems. Water Environment Research Foundation, IWA Publishing, London.

Evans TD (2007) Environmental Impact Study of Food Waste Disposers: a report for The County Surveyors' Society \& Herefordshire Council and Worcestershire County Council. Worcestershire County Council, Worcestershire, UK. See www.timevansenvironment.com (accessed 03/11/2010).

Evans TD, Andersson P, Wievegg A and Carlsson I (2010) Surahammar - a case study of the impacts of installing food waste disposers in fifty percent of households. Water Environment Journal 24(4): 309-319.

Gustafsson A (2008) Slopad avgift för avfallskvarn (Fees for FWDs abolished). Svenska Dagbladet, 1 September 2008. Harrison D (2010) Anaerobic digestion of biowaste in the UK. Proceedings of 15th European Biosolids and Organic Resources Conference. Aqua-Enviro, Leeds.

Hogg D, Barth J, Schleiss K and Favoino E (2007) Dealing with Food Waste in the UK. WRAP, Banbury, UK. See www. wrap.org.uk/document.rm?id=3603 (accessed 20/12/ 2010).

IPCC (Intergovernmental Panel on Climate Change) (2007) Climate change (2007) - Intergovernmental Panel on Climate Change Fourth Assessment Report (AR4). Cambridge University Press, UK. See http://www.ipcc.ch (accessed 19/10/2010).

Jones PH (1990) Kitchen Garbage Grinders (KGGs/Food Waste Disposers) the Effect on Sewerage Systems and Refuse Handling. Institute for Environmental Studies, University of Toronto, Toronto, USA.

Karlberg T and Norin E (1999) VBB VIAK AB.

Köksavfallskvarnar - effekter på avloppsreningsverk, En studie från Surahammar. VA-FORSK RAPPORT 1999-9 (in Swedish). Institute for Environmental Studies, University of Toronto, Toronto, USA.

Kegebein J, Hoffmann E and Hahn HH (2001) Co-transport and co-reuse, an alternative to separate bio-waste collection? Wasser. Abwasser 142: 429-434.

Ketzenberger BA (1995) Water Use by Kitchen Food Waste Disposers in Households. MS thesis, University of Wisconsin-Madison, USA.

Larson M (2010) San Francisco fights FOG. Municipal Sewer and Water Magazine, February, 2010: 14-16.

Levis JW, Barlaz MA, Themelis NJ and Ulloa P (2010)

Assessment of the state of food waste treatment in the United States and Canada. Waste Management 30(8-9): 1488-1489.

Lundie S and Peters GM (2005) Life cycle assessment of food waste management options. Journal of Cleaner Production 13(3): 275-286.

National Energy Foundation (2010) See http://www.nef.org.uk/ greencompany/co2calculator.htm (accessed 14/12/2010).

NRC (National Research Council) (2002) Biosolids Applied to Land: Advancing Standards and Practices. National Academy Press, Washington, DC, USA.

New York City DEP (1999) The impact of food waste disposers in combined sewer areas of New York City. See http://www.nyc.gov/html/dep/pdf/grinders.pdf (accessed 01/02/2012).

NILIM (National Institute for Land and Infrastructure Management) (2005) Report on Social experiment of garbage grinder introduction. Technical note of National Institute for Land and Infrastructure Management, Japan. no. 226, March.

Nilsson P, Lilja G, Hallin P-O, et al. (1990) Waste management at the source utilizing food waste disposers in the home; a case study in the town of Staffanstorp. Department of Environmental Engineering, University of Lund, Sweden.

Quested T and Johnson H (2009) Household Food and Drink Waste in the UK. Report prepared by WRAP, Banbury. See www.wrap.org.uk/document.rm?id $=8048$ (accessed 04/ 12/2010).

Riedel F (2008) Turning contaminated waste into clean renewable energy and PAS110 compost - an overview of the interengineering biowaste process. Proceedings of 13th European Biosolids and Organic Resources Conference and Workshop. Aqua-Enviro, Wakefield.

Smith A, Brown K, Ogilvie S, Rushton K and Bates J (2001) Waste Management Options and Climate Change. Office for Official Publications of the European Communities, Luxembourg, Final report.

Smith SR (1996) Agricultural Recycling of Sewage Sludge and the Environment. CAB International, Wallingford, England.

Smith SR (2000) Are controls on organic contaminants necessary to protect the environment when sewage sludge is used in agriculture? Progress in Environmental Science 2: 129-146. 
Smith SR and Jasim S (2009) Small-scale home composting of biodegradable household waste: overview of key results from a 3-year research programme in West London. Waste Management and Research 27(10): 941-950.

Wouters IM, Douwes J, Doekes G, et al. (2000) Increased levels of markers of microbial exposure in homes with indoor storage of organic household waste. Applied Environmental Microbiology 66(2): 627-631.

Yang X, Okashiro T, Kuniyasu K and Ohmori H (2010) Impact of food waste disposers on the generation rate and characteristics of municipal solid waste. Journal of Material Cycles and Waste Management 12(1): 17-24.

\section{WHAT DO YOU THINK?}

To discuss this paper, please email up to 500 words to the editor at journals@ice.org.uk. Your contribution will be forwarded to the author(s) for a reply and, if considered appropriate by the editorial panel, will be published as discussion in a future issue of the journal.

Proceedings journals rely entirely on contributions sent in by civil engineering professionals, academics and students. Papers should be 2000-5000 words long (briefing papers should be 1000-2000 words long), with adequate illustrations and references. You can submit your paper online via www.icevirtuallibrary.com/content/journals, where you will also find detailed author guidelines. 